
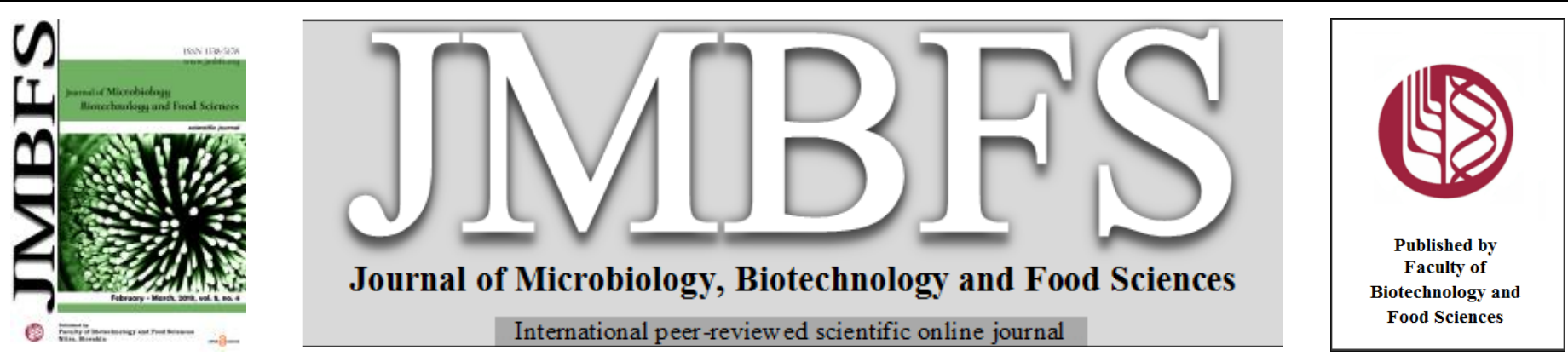

\title{
THE INFLUENCE OF STORAGE CONDITIONS ON THE STALING RATE AND STARCH RETROGRADATION IN WHEAT ROLLS PACKAGED IN A MODIFIED ATMOSPHERE
}

\author{
Izabella Kwaśniewska-Karolak*, Radosław Mostowski
}

Address(es): Dr. Izabella Kwaśniewska-Karolak

Lodz University of Technology, Faculty of Biotechnology and Food Sciences, Institute of Technology and Food Analysis, Stefanowskiego 4/10, 90-924, Lodz, Poland, tel. 0048426312783 .

*Corresponding author: izabella.kwasniewska-karolak@p.lodz.pl

doi: $10.15414 / j m b f s .2019 .8 .5 .1188-1193$

\section{ARTICLE INFO}

Received 10. 4. 2018

Revised 13. 12. 2018

Accepted 10. 1. 2019

Published 1. 4. 2019

Regular article

open 2 access

\section{INTRODUCTION}

Bread staling is a cause of big product waste and financial loses all over the world (Fadda et al., 2014). A useful indicator of bakery products freshness is its characteristic smell, which results from the presence of volatile compounds in the crust and crumb. When baked goods are cooled after baking, the volatile aroma components undergo condensation and absorption in the crumb by starch and proteins (Plessas et al., 2011). The crust components of the characteristic aroma of fresh bakery products are gradually lost with moisture evaporating to the environment. The crumb component levels decrease through further interactions with starch and protein. The intensity of the pleasant smell and taste of bread decreases over a period of time, the length of which has been found to depend on the type of baked goods and storage conditions. The processes typical of baked goods staling are undesirable chemical and enzymatic reactions, which mainly have an oxidative character. Bakery products staling results in reduced elasticity and increased firmness of the crumb (Novotni et al., 2011).

The practice of packaging and storing bakery products in a modified atmosphere (MAP) is becoming increasingly common as a method of extending its shelf life and maintaining good quality, which was confirmed by many authors (Kotsianis et al., 2002; Fik et al., 2012). Some of them emphasize its role in extending the microbial shelf life of bread (Phillips, 1996). Packaging of baked goods under anaerobic protective atmosphere (APA) and storage at low temperatures might either strongly reduce the rate of staling-associated reactions or stop them almost completely. One promising method is modified atmosphere packaging of bakery products, like rolls, combined with storage at refrigeration temperatures. According to many authors, there is a negative dependence between staling rate and temperature (Fadda et al., 2014).

The storage of baked goods at low temperatures causes starch retrogradation, which is one of processes contributing to their staling. Starch retrogradation has short-term and long-term stages. The short-term association of amylose molecules is usually completed within a few hours (Funami et al., 2005). Amylose molecules with relatively low molecular weights are characterized by the highest retrogradation rate (Ishiguro et al., 2000). Because of the high melting temperature of amylose crystals (above $100^{\circ} \mathrm{C}$ ), this process is irreversible under normal conditions (Morris, 1991). The long-term retrogradation based on re-crystallization of amylopectin runs much more slowly than aggregation of amylose chains and can take a few weeks (Ishiguro et al., 2000; Karim and Norziah 2000; Krystyjan et al., 2013). This process is thermally reversible (Morris, 1991).

Despite a number of studies, the mechanism of bakery products staling has not been fully elucidated. An important role in this process is ascribed to starchgluten interactions, leading to cross-links between gluten and gelatinized starch.
However, according to Gambuś (2005), staling of gluten-free baked goods is faster than for goods containing gluten.

Apart from staling, the development of microbial contamination, mainly in the form filamentous fungi, reduces the quality and safety of baked goods during their storage. Modified atmosphere packaging and storage of baked goods do not significantly affect the rate of staling but have a positive impact on microbial stability due to strongly reduced growth of saprophytic bacteria, yeasts and filamentous fungi (Rasmussen and Hansen, 2001). This positive effect was also observed during the storage of other food products (Krala and Kijowski, 2013). The cumulative effect of modified atmosphere packaging and low temperature during the storage of various food products is stronger than when these factors are used separately.

Previously described methods used to extend the freshness of baked goods are based on the addition of various substances, like enzyme preparations, emulsifiers, hydrocolloids, oxidizing or reducing substances, treatment with ionizing radiation, rapid and controlled cooling immediately after baking, packaging under aseptic conditions, modified atmosphere packaging, and freezing. A combination of modified atmosphere packaging and storage at low temperatures significantly extends the period of acceptable quality of baked goods without chemical preservatives. Certain sorts of baked goods may be kept in a modified atmosphere at ambient temperature for even a month without significant changes in the physicochemical properties. The inhibiting effect of modified atmosphere packaging on microbial growth increases with the concentration of carbon dioxide in the atmosphere (Krala and Kijowski, 2013). Since bakery products are one of the most frequently consumed food products, this study aimed to elucidate the effect of a modified atmosphere $\left(70 \% \mathrm{CO}_{2}\right.$ and $30 \% \mathrm{~N}_{2}$ ) on the quality and starch retrogradation rate of wheat rolls stored at different temperature conditions

$\left(-18{ }^{\circ} \mathrm{C}\right.$ and $\left.1^{\circ} \mathrm{C}\right)$

\section{MATERIAL AND METHODS}

\section{Preparation of wheat rolls and storage condition}

Wheat rolls were produced under industrial conditions during one shift in a bakery that packages bread in a modified atmosphere. The wheat rolls were made according to the following formulations (parts determined on weight basis): 50 parts wheat flour type 550 (according to ash content) with $11 \%$ protein content; 30 parts water; 4 parts oil; 1 part salt; 1.5 parts baker's yeast; 1.5 parts baking mix (gluten, glucose, soy flour, ascorbic acid, and mono and diglycerides of fatty acids). 


\section{Bread making and packaging}

Measurement of raw materials used an automated system, tightly coupled with the production tanks. Dispensers were used for the metered water. The fina dough temperature was about $25^{\circ} \mathrm{C}$. All ingredients were mixed in two stages using a Kronos Spiral Mixer: 200 seconds at low speed (25/25) and 250 seconds at high speed (60/60). The resulting dough was left to rise for $60 \mathrm{~min}$ at $30^{\circ} \mathrm{C}$ After shaping into long baguettes, the dough was placed in loaf tins for final fermentation for $100 \mathrm{~min}$ at $35^{\circ} \mathrm{C}$ in a humidity of $75 \%$. The rolls were baked in the first phase at a temperature of $250{ }^{\circ} \mathrm{C}$ and in the second phase at $200{ }^{\circ} \mathrm{C}$ for $15 \mathrm{~min}$ in Miwe electric oven. They were cooled at room temperature and packed in polyamide/polyethylene (1 mm thickness) bags in a modified atmosphere $\left(70 \% \mathrm{CO}_{2}, 30 \% \mathrm{~N}_{2}\right)$ using Tepro LPT 200 packing machine.

\section{Storage conditions}

Part of the material was kept for analyses, while the remainder was divided into 2 parts. One part, designated MAP-DF, was frozen and kept for 10 weeks at -18 ${ }^{\circ} \mathrm{C}$ in a Samsung freezer. The second, designated in MAP-R, was cooled and kept for 9 weeks at $1{ }^{\circ} \mathrm{C}$ in a Samsung refrigerator. Temperature fluctuations amounted to $\pm 1{ }^{\circ} \mathrm{C}$. Before analyses, the rolls kept at $1{ }^{\circ} \mathrm{C}$ were warmed to room temperature while frozen rolls were slowly thawed (2-3 h, temperature $15^{\circ} \mathrm{C}$ ) in closed bags to ensure uniform warming and to avoid condensation of humidity on their cold surface. After thawing, they were warmed to the room temperature.

\section{Chemical composition}

The moisture content in the crumb was determined according to Polish Standard (1996). Samples of rolls $(5 \mathrm{~g}$, weighed with the precision of $0.0001 \mathrm{~g}$ ) were put in vials and dried to constant mass for $3 \mathrm{~h}$ at $105^{\circ} \mathrm{C}$. The results are the means of 3 independent assays. The moisture content was reported as a percentage.

The protein content in rolls was determined using the Kjeldahl method ( $\mathrm{N}=5.7)$ (Polish Standard). The results are the means of 3 independent assays. In order to calculate the total protein content, the nitrogen content should be multiplied by 5.7. Total protein content was reported as $\mathrm{g}$ of protein per 100 grams of the product.

Lipids were quantified according to Weibull-Soxhlet method (Polish Standard). Samples of rolls $(8 \mathrm{~g})$ were treated for $30 \mathrm{~min}$ with $25 \% \mathrm{HCl}$ to release lipid substances, which were separated from the soluble fractions by filtration and extracted with petroleum ether for $1.5 \mathrm{~h}$ using a Tecator unit. Lipid content was calculated based on the decrease in the sample's dry mass. The results are the means of 3 independent assays. The total lipid content was reported as $\mathrm{g}$ of lipids per 100 grams of the product.

\section{Determination of acidity}

The acidity of the rolls was determined according to Polish Standard (1996) Samples of rolls $(25 \mathrm{~g}$, weighed with a precision of $0.01 \mathrm{~g}$ ) were placed in dry 500 $\mathrm{ml}$ Erlenmeyer flasks sealed with rubber plugs and suspended in $250 \mathrm{ml}$ of distilled water (temperature of $60 \pm 2{ }^{\circ} \mathrm{C}$ ). They were vigorously mixed for $3 \mathrm{~min}$, left for $3 \mathrm{~min}$ without mixing and then mixed again for $1 \mathrm{~min}$. The resulting suspensions were filtered through cotton wool into dry Erlenmeyer flasks. Three portions of filtrate $(50 \mathrm{ml})$ were placed in $100 \mathrm{ml}$ flasks and titrated with $\mathrm{NaOH} 0.1 \mathrm{~m}$ until a pale pink color was obtained and remained stable for $1 \mathrm{~min}$, using 3-4 drops of $1 \%$ phenolphtalein as the $\mathrm{pH}$ indicator.

The results are the means of 3 independent assays. The degree of bread acidity was expressed in terms of millilitres of $\mathrm{NaOH} 0.1 \mathrm{M}$ solution required to neutralize the free acids contained in $100 \mathrm{~g}$ of the wheat rolls.

The acidity was calculated as follows:

$X=2 d$ [ acidity $]$

where:

$\mathrm{d}$ is the volume of sodium hydroxide solution (ml) used for titration.

\section{Blue value determination}

The complex of amylose with iodine produces a blue color. Its intensity can be used to indicate the level of free amylose in a soluble fraction, which informs about starch retrogradation. The blue value was determined using a spectrophotometric method (Skotnicka and Palich, 2007; Fik et al., 2012). $10 \mathrm{~g}$ of the crumb was homogenized with $50 \mathrm{ml}$ of water for $2 \mathrm{~min}$. Then the homogenate was mixed at room temperature for $20 \mathrm{~min}$ using a magnetic stirrer. The slurry was centrifuged (1600 g, $10 \mathrm{~min}) .2 \mathrm{ml}$ of Carrez I and $2 \mathrm{ml} \mathrm{Carrez} \mathrm{II}$ solutions were added to precipitate the protein matter. The whole sample was carefully mixed, allowed to stand for $10 \mathrm{~min}$ and finally centrifuged $(5000 \mathrm{~g}, 5$ min). Afterwards, $4 \mathrm{ml}$ of the supernatant was mixed with $25 \mathrm{ml}$ of iodine solution $(0.04 \%)$. The blue value was expressed as the absorbance measured at $580 \mathrm{~nm}$ using distilled water as a blank.

\section{Determination of resistant starch content by DSC}

Resistant starch (RS) fractions in the rolls were isolated with using $\alpha$-amylase (Pancreatic $\alpha$-Amylase, Megazyme) and amyloglucosidase (Megazyme, 2002). Each sample of rolls $(20 \mathrm{~g})$ was incubated with $200 \mathrm{ml}$ of $\alpha$-amylase and amyloglucosidase solution at $37^{\circ} \mathrm{C}$ for $16 \mathrm{~h}$. The reaction was terminated with 20 $\mathrm{ml}$ of $99 \%$ ethanol. The samples were centrifuged for $10 \mathrm{~min}$ at $3000 \mathrm{~g}$ and the solids were suspended in $2 \mathrm{ml}$ of $50 \%$ ethanol, mixed with $30 \mathrm{ml}$ of $50 \%$ ethanol and centrifuged under the same conditions as before. This procedure was repeated. After the centrifuging, the solids (the RS fraction) were lyophilized.

Differential scanning calorimetry measurements were carried out to determine the content of RS and type of RS polymorph (retrograded amylose and amylopectin) contained in the tested rolls using a Mettler Toledo Differential Scanning Calorimeter DSC-1. This method enables the determination of the melting temperature of RS crystals and the enthalpy of this process. Samples of starch isolated from rolls $(3 \mathrm{mg})$ were placed in hermetically sealed aluminum pans, heated from $20^{\circ} \mathrm{C}$ to $220^{\circ} \mathrm{C}$ and then cooled to $20^{\circ} \mathrm{C}$ at a scanning rate of $3{ }^{\circ} \mathrm{C} \mathrm{min}^{-1}$. An empty pan was used as a reference. The parameters of scanning allowed observation of the melting of retrograded amylose and amylopectin (RS). The melting temperature and enthalpy of RS and its polymorph were found from the obtained thermograms. An endothermal peak characterized RS melting. The analysis of thermograms included determination of temperature corresponding to the minimum of the endothermal peak. Enthalpy of RS melting $\left(\Delta \mathrm{H} \mathrm{J} \mathrm{g}^{-1}\right)$ was calculated based on the surface area between the peak and baseline and then expressed as dry mass (Sievert and Pomeranz, 1990). The results are the means of 3 independent measurements.

\section{Crystallinity of starch}

Crystallinity of starch isolated from the rolls (after lyophilization) was measured by wide-angle X-ray scattering using a Bruker AXS D5005 X-ray diffractometer The X-ray generator equipped with a copper tube operating at $40 \mathrm{kV}$ and $50 \mathrm{~mA}$ produced radiation of approximately $154 \mathrm{~nm}$ wavelength. Data were recorded over an angular rate of $4^{\circ}$ to $38^{\circ}$ (Ribotta et al., 2004).

\section{Crumb texture measurements}

Crumb firmness measurements were performed using a Texture Analyzer TA.XT Plus governed by Texture Exponent 32 software (Stable Microsystems). Wheat rolls samples were subjected to texture profile analysis (TPA) (Ronda and Caballero, 2011). The samples were cubes with $20 \mathrm{~mm}$ sides. They were compressed twice with an aluminum cylinder-shaped plunger with a diameter of $100 \mathrm{~mm}$ to a depth of $50 \%$ strain. The plunger moved at a rate of $1 \mathrm{~mm} \mathrm{~s}^{-1}$ and the time between strokes was $2 \mathrm{~s}$. The apparatus recorded the force exerted by the plunger as a function of time, from which texture parameters hardness and springiness were determined. Hardness was defined as the peak force $[\mathrm{N}]$ during the first compression cycle. These analyses were performed in eightfold.

\section{Statistical analysis}

All measurements and analyses were carried out in triplicate (except crumb texture). The data were presented as the means \pm standard deviations. The results were subjected to an analysis of variance in the two-way ANOVA using Statistica 7.1 software. Tukey's test was used to assess differences between means. The significance of differences was considered at the level of $\mathrm{p} \leq 0.05$.

\section{RESULTS AND DISCUSSION}

\section{Chemical composition}

The results of chemical analyses of the tested rolls were as follows: protein 6.42 $\mathrm{g} / 100 \mathrm{~g}^{-1}$ dry weight, lipids $2.72 \mathrm{~g} / 100 \mathrm{~g}^{-1}$ dry weight, and dry weight $67.26 \%$. This composition is typical for this type of wheat roll (Borkowska and Lagowska, 2014). During cooling and freezing storage, protein and fat content changes were not observed. We noticed some fluctuations of moisture content and acidity in both frozen and refrigerated wheat rolls. The increase in crumb hardness was more significant in case of refrigerated storage. Observed changes of the blue value and calorimetric analyzes, showed that during storage at a reduced temperature, the process of starch retrogradation in wheat rolls proceeded. The amount of retrogradated starch increased with the storage time and was more intense during freezing.

\section{Moisture changes}

The fresh product had the highest moisture content. The analysis of moisture content in the crumb of the tested rolls showed that this parameter gradually 
decreased with time regardless of storage conditions (Tables 1,2). At the end of 10 weeks, the moisture of the frozen rolls' crumb had decreased to $28.53 \pm$ $0.21 \%$ (by $12 \%$ ) and that in the refrigerated rolls to $30.14 \pm 0.12 \%$ (by $7.6 \%$ ).

The gradual loss of moisture during frozen storage might be associated with sublimation of the ice, but also due to the low permeability of the package. The process of starch retrogradation is quite intensive under freezing and cooling conditions and it causes the release of the water previously bound by starch grains during gelatinization. Its migration towards the crust during storage might have caused its rapid evaporation and loss.

The temperature and the time of storage had a significant impact on the decline in the moisture level in the crumb of rolls. A small but statistically significan decrease in moisture content in the refrigerated rolls was observed after 2 weeks of storage, while in the frozen ones this decrease was observed after 7 weeks. The significant differences between the moisture content in the crumb of refrigerated $\left(\mathrm{T}=1{ }^{\circ} \mathrm{C}\right)$ and frozen $\left(\mathrm{T}=-18^{\circ} \mathrm{C}\right)$ rolls was noticed after six weeks of storage.

Taking into consideration the results of the statistical analysis of the experimental data related to the moisture content in the crumb of rolls, it could be stated that both the time and storage conditions significantly affected this parameter.
The decreasing moisture level is one of factors responsible for the reduction in the quality of baked goods, as manifested by the hard and dry crumb and the lack of crust crispness. However, it is very difficult to avoid this phenomenon during long-term storage (Patel et al., 2005). The packaging permeability has a very strong impact on the extent of moisture loss, the residual water activity of the bread and the humidity of the surrounding atmosphere (Novotni et al., 2011) The decline in moisture observed during the storage of baked goods correlates with the progress of starch retrogradation and crumb staling. The study of Le Bail et al. (2009), confirmed this conclusion. They noted a strong decrease in the water-holding capacity of starch during baked goods storage. Moisture diffusion from the crumb to the crust was followed by either its condensation on the inner side of the packaging or diffusion into the environment, which depended on the packaging permeability. In our study, the decreasing moisture level of the rolls might result from the decreasing water-holding capacity of the crumb. The latter parameter decreased faster in the frozen rolls than in the refrigerated ones.

Table 1 Effect of storage time on TPA and some physicochemical changes in refrigerated wheat rolls

\begin{tabular}{|c|c|c|c|c|c|c|c|c|c|c|c|}
\hline \multirow[b]{2}{*}{ Parameter } & \multicolumn{11}{|c|}{ Storage week } \\
\hline & 0 & 1 & 2 & 3 & 4 & 5 & 6 & 7 & 8 & 9 & 10 \\
\hline Water content & 32.65 & 32.51 & 31.78 & 31.69 & 31.51 & 31.23 & 30.31 & 30.67 & 30.52 & 30.45 & 30.14 \\
\hline$[\%]$ & $\pm 0.14^{\mathrm{a}}$ & $\pm 0.06^{\mathrm{a}}$ & $\pm 0.12^{\mathrm{b}}$ & $\pm 0.09^{\mathrm{b}}$ & $\pm 0.05^{\mathrm{b}}$ & $\pm 0.06^{\mathrm{b}}$ & $\pm 0.11^{\mathrm{c}}$ & $\pm 0.13^{c}$ & $\pm 0.09^{c}$ & $\pm 0.24^{\mathrm{c}}$ & $\pm 0.12^{\mathrm{c}}$ \\
\hline Crystallinity & nd & nd & nd & nd & nd & $\begin{array}{l}20.8 \\
\pm 1.70^{\mathrm{a}}\end{array}$ & $\begin{array}{l}23.8 \\
\pm 2.10^{\mathrm{a}}\end{array}$ & $\begin{array}{l}24.2 \\
\pm 2.40^{\mathrm{a}} \\
\end{array}$ & $\begin{array}{l}24.4 \\
\pm 1.40^{\mathrm{a}}\end{array}$ & $\begin{array}{l}24.6 \\
\pm 2.50^{\mathrm{a}} \\
\end{array}$ & $\begin{array}{l}25.8 \\
\pm 1.70^{\mathrm{a}}\end{array}$ \\
\hline $\begin{array}{l}\text { Acidity } \\
{\left[^{\circ}\right]}\end{array}$ & $\begin{array}{l}3.67 \\
\pm 0.20^{\mathrm{a}} \\
\end{array}$ & $\begin{array}{l}3.67 \\
\pm 0.10^{\mathrm{a}} \\
\end{array}$ & $\begin{array}{l}3.66 \\
\pm 0.20^{\mathrm{a}} \\
\end{array}$ & $\begin{array}{l}3.67 \\
\pm 0.20^{\mathrm{a}} \\
\end{array}$ & $\begin{array}{l}3.67 \\
\pm 0.10^{\mathrm{a}} \\
\end{array}$ & $\begin{array}{l}3.67 \\
\pm 0.20^{\mathrm{a}} \\
\end{array}$ & $\begin{array}{l}3.66 \\
\pm 0.40^{\mathrm{a}} \\
\end{array}$ & $\begin{array}{l}3.67 \\
\pm 0.30^{\mathrm{a}} \\
\end{array}$ & $\begin{array}{l}3.67 \\
\pm 0.20^{\mathrm{a}} \\
\end{array}$ & $\begin{array}{l}3.67 \\
\pm 0.10^{\mathrm{a}} \\
\end{array}$ & $\begin{array}{l}3.66 \\
\pm 0.10^{\mathrm{a}} \\
\end{array}$ \\
\hline $\begin{array}{l}\text { Hardness } \\
{[\mathrm{N}]}\end{array}$ & $\begin{array}{l}48.25 \pm \\
3.27^{\mathrm{a}}\end{array}$ & $\begin{array}{l}52.13 \pm \\
5.04^{\mathrm{a}}\end{array}$ & $\begin{array}{l}55.17 \pm \\
2.08^{\mathrm{a}}\end{array}$ & $\begin{array}{l}59.99 \pm \\
2.11^{\mathrm{b}}\end{array}$ & $\begin{array}{l}63.22 \pm \\
4.24^{\mathrm{b}}\end{array}$ & $\begin{array}{l}69.24 \pm \\
3.23^{\mathrm{b}}\end{array}$ & $\begin{array}{l}76.18 \pm \\
4.12^{\mathrm{c}}\end{array}$ & $\begin{array}{l}80.58 \pm \\
3.66^{c}\end{array}$ & $\begin{array}{l}82.56 \pm \\
5.12^{\mathrm{c}}\end{array}$ & $\begin{array}{l}86.22 \pm \\
5.48^{c}\end{array}$ & $\begin{array}{l}87.55 \pm \\
5.48^{c}\end{array}$ \\
\hline
\end{tabular}

$\overline{\mathrm{a}, \mathrm{b}, \mathrm{c}}$ Mean values in the same row designated with different letters are significantly different $(\alpha=0.05)$; nd. - not determined

Table 2 Effect of storage time on TPA and some physicochemical changes in deeply frozen wheat rolls

\begin{tabular}{|c|c|c|c|c|c|c|c|c|c|c|c|}
\hline \multirow[b]{2}{*}{ Parameter } & \multicolumn{11}{|c|}{ Storage week } \\
\hline & 0 & 1 & 2 & 3 & 4 & 5 & 6 & 7 & 8 & 9 & 10 \\
\hline \multirow{2}{*}{$\begin{array}{l}\text { Water content } \\
{[\%]}\end{array}$} & 32.65 & 32.62 & 32.52 & 32.47 & 31.80 & 31.63 & 31.24 & 30.32 & 30.27 & 28.69 & 28.53 \\
\hline & $\pm 0.14^{\mathrm{a}}$ & $\pm 0.11^{\mathrm{a}}$ & $\pm 0.09^{\mathrm{a}}$ & $\pm 0.14^{\mathrm{a}}$ & $\pm 0.25^{\mathrm{a}}$ & $\pm 0.22^{\mathrm{a}}$ & $\pm 0.21^{\mathrm{a}}$ & $\pm 0.18^{\mathrm{b}}$ & $\pm 0.18^{\mathrm{b}}$ & $\pm 0.13^{\mathrm{c}}$ & $\pm 0.13^{\mathrm{c}}$ \\
\hline \multirow[t]{2}{*}{ Crystallinity } & nd. & nd. & nd. & nd. & nd. & 22.20 & 23.10 & 26.30 & 26.70 & 28.50 & 30.00 \\
\hline & & & & & & $\pm 2.10^{\mathrm{a}}$ & $\pm 1.80^{\mathrm{a}}$ & $\pm 2.40^{\mathrm{b}}$ & $\pm 2.00^{\mathrm{b}}$ & $\pm 1.50^{\mathrm{b}}$ & $\pm 2.40^{\mathrm{b}}$ \\
\hline \multirow{2}{*}{$\begin{array}{l}\text { Acidity } \\
{\left[^{\circ}\right]}\end{array}$} & 3.67 & 3.66 & 3.67 & 3.67 & 3.66 & 3.67 & 3.67 & 3.66 & 3.67 & 3.67 & 3.66 \\
\hline & $\pm 0.10^{\mathrm{a}}$ & $\pm 0.20^{\mathrm{a}}$ & $\pm 0.20^{\mathrm{a}}$ & $\pm 0.10^{\mathrm{a}}$ & $\pm 0.30^{\mathrm{a}}$ & $\pm 0.10^{\mathrm{a}}$ & $\pm 0.10^{\mathrm{a}}$ & $\pm 0.20^{\mathrm{a}}$ & $\pm 0.20^{\mathrm{a}}$ & $\pm 0.20^{\mathrm{a}}$ & $\pm 0.10^{\mathrm{a}}$ \\
\hline \multirow{2}{*}{$\begin{array}{l}\text { Hardness } \\
{[\mathrm{N}]}\end{array}$} & 48.25 & 46.69 & 47.02 & 48.19 & 53.12 & 54.87 & 58.89 & 61.29 & 69.56 & 78.79 & 81.04 \\
\hline & $\pm 3.27^{\mathrm{a}}$ & $\pm 3.46^{\mathrm{a}}$ & $\pm 1.82^{\mathrm{a}}$ & $\pm 2.08^{\mathrm{a}}$ & $\pm 2.02^{\mathrm{b}}$ & $\pm 2.86^{\mathrm{b}}$ & $\pm 2.75^{\mathrm{b}}$ & $\pm 3.03^{\mathrm{b}}$ & $\pm 3.53^{\mathrm{c}}$ & $\pm 3.02^{\mathrm{c}}$ & $\pm 5.23^{\mathrm{c}}$ \\
\hline
\end{tabular}

\section{Acidity of rolls}

Bakery products acidity has a significant impact on the crumb texture, the more desirable characteristics of flavor, the freshness of the bread, and the resistance to the effects of harmful aerobic bacteria. Wheat products are characterized by low acidity, indicated that the acidity of good quality wheat bread should be within 3 $5^{\circ}$. The initial acidity of the studied rolls was $3.67^{\circ}$ (Tab. 1,2 ). This value was consistent with the findings of other studies (Borkowska and Lagowska, 2014) The acidity did not change over the entire storage period. Some authors suggest that modified atmospheres with high carbon dioxide concentrations have a negative influence on the sensory properties of baked goods packaged in them (Fik et al., 2012). Although the modified atmosphere used in this study contained as much as $70 \% \mathrm{v} / \mathrm{v}$ carbon dioxide, the sensory attributes of the rolls were not found to be altered.

\section{Blue value}

The blue value (measured as absorbance) defines the content of water-soluble starch in a baked goods sample. Its amount in the crumb generally decreases as bread products stale. The rate of bread staling depends on many factors resulting from the manufacturing process and storage conditions. In addition, the blue value provides evidence of RS development. As a result of starch reorganization, crystallized starch become insoluble. Water previously trapped in gelatinized starch, due to its retrogradation, systematically migrates and vaporizes, becoming less accessible for starch (Fik et al., 2000). As a result, insoluble, retrograded starch cannot form complexes with iodine. When the absorbance values are close to zero, we can conclude that the starch has been totally transformed into RS. The blue value decreased over time in both refrigerated and frozen rolls. The dynamics of these changes correlated closely with the time of storage and was similar regardless of the ambient temperature conditions. This is consistent with results reported by Skotnicka and Palich (2007), who also found that freezing did not protect bread from staling.

Low absorbance values measured after 10 weeks' storage indicated a far-reaching staling process. Rolls characterized by such values were not suitable for consumption. The crumb was hard and crumbly, and the skin dull. In wheat rolls packed in a modified atmosphere, the value decreased considerably (by $50 \%$ compared to the initial value) after only 2 weeks regardless of storage temperature (Fig 1). By the end of the storage period, a huge drop in the blue value was observed $(90 \%)$.

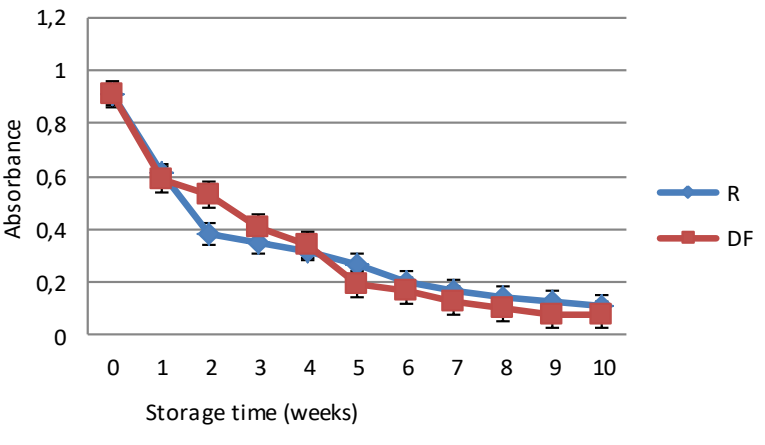

Figure 1 Changes in the blue number values during the storage of tested refrigerated (R) and deeply frozen (DF) wheat rolls 


\section{Starch retrogradation by DSC}

Starch chains contained in the dough have a native, crystalline and ordered structure. Baking gelatinizes starch while the storage of baked goods results in starch retrogradation. During storage, starch chains re-associate to form the ordered crystalline structure that was damaged by gelatinization during baking. Reorganization of the starch structure during storage of baked goods is accompanied by a gradual increase in the content of resistant starch (RS), which contributes to changes in the crumb texture and staling (Fik et al., 2012).
Crystallization of starchy materials into RS is a result of the re-association of amylose chains in the form of double helices that are loosely arranged into partially crystalline system that resists the diffusion and binding of hydrolytic enzymes (Eerlingen and Delcour, 1995). The increase in RS content during storage of the investigated wheat rolls was estimated by differential scanning calorimetry (Table 3).

Table 3 Melting temperature and enthalpy of RS contained in the refrigerated and frozen rolls

\begin{tabular}{|c|c|c|c|c|}
\hline \multirow{3}{*}{$\begin{array}{l}\text { Storage period } \\
\text { (week) }\end{array}$} & \multicolumn{4}{|c|}{ Storage condition / parameter } \\
\hline & Refrigerated & Deeply frozen & Refrigerated & Deeply frozen \\
\hline & Temperature $\mathrm{T}_{\mathrm{p}}\left[{ }^{\circ} \mathrm{C}\right]$ & & Enthalpy $\Delta \mathrm{H}\left[{\left.\mathrm{J} / \mathrm{g}^{-1}\right]}^{-1}\right.$ & \\
\hline 0 & - & - & - & - \\
\hline 5 & $166.20 \pm 1.10^{\mathrm{a}}$ & $162.40 \pm 2.12^{\mathrm{a}}$ & $82.45 \pm 2.50^{\mathrm{a}}$ & $75.30 \pm 1.10^{\mathrm{a}}$ \\
\hline 6 & $177.50 \pm 2.00^{\mathrm{b}}$ & $167.60 \pm 3.10^{\mathrm{a}}$ & $95.21 \pm 3.00^{\mathrm{b}}$ & $110.70 \pm 1.20^{\mathrm{b}}$ \\
\hline 7 & $169.50 \pm 1.00^{\mathrm{c}}$ & $163.90 \pm 2.83^{\mathrm{a}}$ & $100.25 \pm 3.70^{\mathrm{b}}$ & $115.20 \pm 2.10^{\mathrm{b}}$ \\
\hline 8 & $164.10 \pm 2.11^{\mathrm{d}}$ & $167.20 \pm 2.05^{\mathrm{a}}$ & $104.86 \pm 2.01^{\mathrm{b}}$ & $116.90 \pm 3.05^{b}$ \\
\hline 9 & $168.10 \pm 1.85^{\mathrm{e}}$ & $165.50 \pm 2.64^{\mathrm{a}}$ & $109.20 \pm 2.60^{\mathrm{b}}$ & $120.20 \pm 2.70^{\mathrm{b}}$ \\
\hline 10 & $171.10 \pm 2.11^{\mathrm{e}}$ & $175.20 \pm 1.92^{\mathrm{b}}$ & $113.20 \pm 1.83^{\mathrm{c}}$ & $123.80 \pm 3.16^{b}$ \\
\hline
\end{tabular}

Fresh rolls (time 0 ) did not contain RS. After 5 weeks of storage at $\mathrm{T}=1{ }^{\circ} \mathrm{C}$ or $\mathrm{T}$ $=-18{ }^{\circ} \mathrm{C}$, an endothermic peak, characteristic of retrograded starch, was visible in the DSC curves (Fig 2). Increasing values of starch melting enthalpy provided evidence of the gradual rise in RS content in these rolls (Table 3). The melting enthalpies of starch reflect the extent of its retrogradation during storage. Values of $\Delta \mathrm{H}$ are also correlated with the degree of starch crystallinity, since the melting of crystallites requires more energy (Sievert and Pomeranz, 1990; Chen et al. 2015). The highest enthalpy values were observed for the frozen rolls after 10 weeks. The results of DSC measurements showed that the frozen rolls contained more RS than the refrigerated ones. The melting temperatures of RS characterize the susceptibility of starch to melting. The higher the value, the more energy is required to initiate the process (Coral et al., 2009). RS melting temperatures gradually increased from $162.4{ }^{\circ} \mathrm{C}$ to $175.2{ }^{\circ} \mathrm{C}$ over the period of storage, which could be a consequence of gradual reorganization of starch structure into a more ordered, crystalline structure. More ordered structures, impact the thermal stability and the enzyme susceptibility of the RS (Kiatponglarp et al., 2015) Both the DSC results and blue value measurements provide evidence that starch retrogradation was faster in the frozen rolls than in the refrigerated ones, and the storage of baked goods always brings about the appearance of RS. This finding is consistent with results reported by Barcenas et al. (2003).

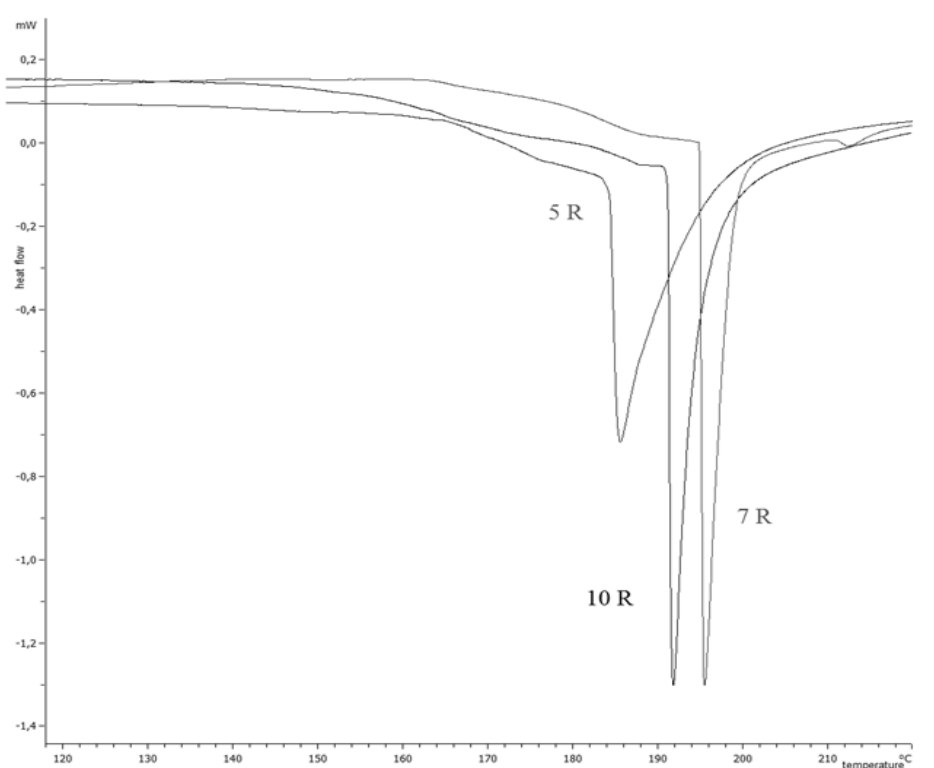

Figure 2 DSC curve of RS isolated from rolls kept for 5, 7 and 10 weeks at $\mathrm{t}=$ ${ }^{\circ} \mathrm{C}$

After 10 weeks of storage, the increase in RS content (based on the $\Delta \mathrm{H}$ enthalpy changes) was higher in the frozen rolls. In case of refrigerated wheat rolls the enthalpy value increased by $37 \%$ and in frozen by $64 \%$. The potentia effect of refrigerated or frozen rolls on consumers' health may be positive because RS is a dietary fiber component with prebiotic effects and associated health benefits for the colon (Topping and Clifton, 2001). It is also considered beneficial for the dietary management of metabolic and lifestyle disorders, including obesity, type-II diabetes and hyperlipidemia (Kim et al., 2003). RS is a dietary fiber component and its presence is beneficial for health of consumers. As dietary fiber is essential for the functioning of the human gastro-intestinal tract (Haralampu, 2000; Fuentes-Zaragoza et al., 2010), baked goods with elevated RS levels may be regarded healthy food products.

Changes in the moisture level and RS melting enthalpy were negatively correlated (correlation coefficients of -0.84 and -0.69 for the refrigerated and frozen rolls, respectively). These values may suggest that processes of moisture migration and reorganization of starch structure in the investigated rolls were related.

\section{Crystallinity of RS}

X-ray powder crystallography was used to determine changes in starch crystallinity during storage of the rolls. Crystallinity, which can be interpreted as long-range order, in a semicrystalline biopolymer like starch, is defined as the ratio between the mass of the crystalline domains and the total mass of the material. The semi-crystalline diffraction pattern is composed of crystalline diffraction peaks superimposed on an amorphous background (Yu et al., 2013).

X-ray spectra of gelatinized starch revealed its fully amorphous character Reorganization of starch structure during the storage of the rolls caused its partia recrystallization, which was reflected in the peaks visible in the diffractograms (Fig 3). In study conducted by Ribotta et al. (2004), it was noticeable that peak intensities, i.e. starch crystallinity, increased with storage time of bread. The difference in crystallinity in the wheat rolls may be attributed to the difference in the amount and structure order of RS. A higher degree of crystallinity provides structural stability and makes the granules more resistant to enzymatic digestion. $\mathrm{X}$-ray diffractograms of starch samples that were isolated from the rolls showed the crystalline form, corresponding to the peaks at the wavelengths of $15^{\circ}, 17^{\circ}$ and $23^{\circ}$. These peaks were characterized by lower intensity than native starch.

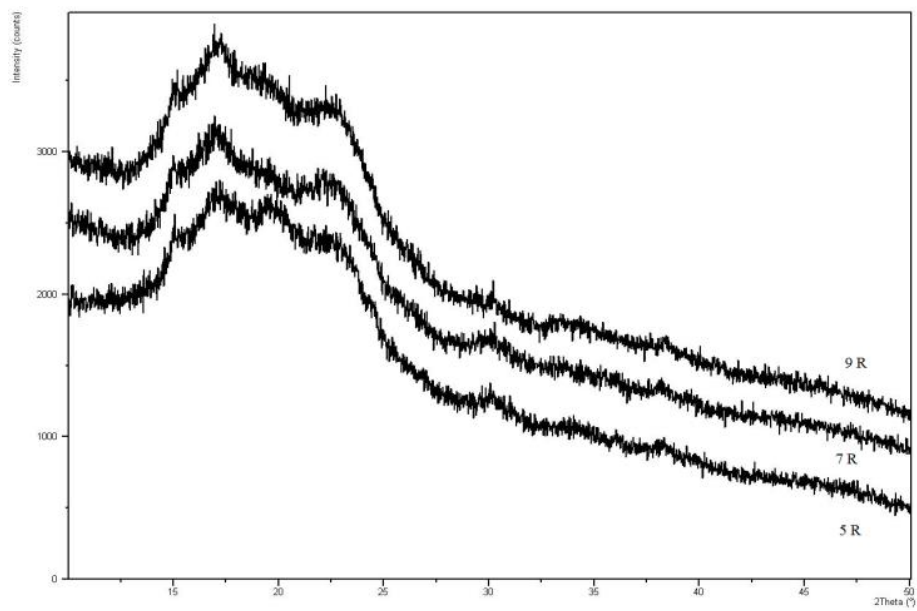

Fig 3 RS diffractograms for roll samples after 5, 7 and 9 weeks of the refrigerated storage

The crystallinity of starch was calculated based on the diffractograms as a ratio of the surface area under the peaks to the whole surface area of the diffractogram. The difference in crystallinity in the wheat rolls may be attributed to the difference in the amount and structure order of RS. A higher degree of crystallinity provides structural stability and makes the granules more resistant to enzymatic digestion. In conducted research, it has been demonstrated that starch 
crystallinity increased during bread staling (Tables 1,2). The values of starch crystallinity in the wheat rolls tend to be lower than the crystallinity of native wheat starch, reaching around 40\%, depending on the cultivar (Majzoobi et al. 2011). The presence of crystalline structures suggested advanced reorganization of starch structure, caused by storage of the rolls under the tested conditions. It means that gelatinized, completely amorphous starch granules underwent partial re-crystallization. During baking, starch gelatinizes and becomes fully amorphous. Such starch structures are susceptible to enzyme attack. Increasing the amount and order growth of crystal RS structures increases the resistance to degradation. As a result, the formed RS is not available and not susceptible to enzymatic hydrolysis. The process of RS crystallization observed during wheat rolls storage was also reported by other authors (Ribotta et al., 2004; PrimoMartin et al., 2007).

\section{Texture of rolls}

Changes in the hardness and springiness of the crumb of rolls were determined using texture profile analysis (TPA). Individual texture characteristics of the crumb were assessed at regular intervals throughout the storage period.

The hardness of the crumb increased during the whole period of storage of both the refrigerated and frozen rolls. In case of the refrigerated rolls, the hardness increased during 10 weeks of storage from around 48.25 to $87.55 \mathrm{~N}$. In case of the frozen rolls this parameter decreased after the first week and significantly increased (by 35\%) after 7 weeks, when the sensory properties were no longer acceptable for the consumers. Statistical analysis of the measured hardness values, showed, that both the time and storage conditions strongly affected this parameter.

The measurements revealed, that the texture of refrigerated rolls quickly worsened (Tables 1,2). A similar effect was reported previously. The increasing crumb firmness was caused by conversion of the starch contained in rolls. Patel et al. (2005), found that these changes depended not only on storage conditions but also on many other factors like the rate of heating during baking, which is responsible for the degree of hydration and swelling of the starch as well as the degree of order of crystalline regions of amylopectin and amylose chains located inside the crumb.

\section{CONCLUSIONS}

The shelf life of frozen baked goods packaged under a modified atmosphere is longer than that of refrigerated baked goods with the same packaging. Although freezing does not completely eliminate staling of baked goods, it strongly reduces the rate of this process. In addition, refrigeration at a temperature of $\mathrm{T}=1{ }^{\circ} \mathrm{C}$ does not accelerate the formation of RS, contrary to previous reports.

Freezing at a temperature of $\mathrm{T}=-18{ }^{\circ} \mathrm{C}$ maintained acceptable quality for the rolls for 6 weeks, which is 3-fold longer than the manufacturer's declared shelflife for the refrigerated rolls.

The temperature of storage significantly affected RS development. This process was faster in case of frozen rolls, as proved using blue value and starch melting enthalpy measurements. The development of crystalline starch structures during bread storage was similar in both storage conditions. Relatively small changes in the moisture levels of the refrigerated and frozen rolls had no significant impact on their sensory quality. The decrease in crumb springiness of the frozen rolls was relatively slow while the crumb of refrigerated rolls became hard after the first week of storage. This difference suggests that freezing is better than refrigeration for maintaining baked goods texture (i.e., hardness and springiness of the crumb). After a longer period of storage, frozen wheat rolls outperformed refrigerated ones in terms of quality (sensory attributes, hardness and springiness of the crumb)

\section{REFERENCES}

BARCENAS, M.E., HAROS, M., BENEDITO, C., ROSELL C.M. 2003. Effect of freezing and frozen storage on the staling of part-baked bread. Food Research International, 36, 863-869. https://doi.org/10.1016/S0963-9969(03)00093-0 BORKOWSKA, B., ŁAGOWSKA, U. 2014. Ocena porównawcza jakości pieczywa tradycyjnego i ekologicznego. Zeszyty Naukowe Akademii Morskiej w Gdyni, 86, 210-217.

CHEN, P., LIU, X., ZHANG, X., SANGWAN, P., YU, L. 2015. Phase transition of waxy and normal wheat starch granules during gelatinization. International Journal of Polymer Sciences, Volume 2015:Article ID 397128. http://dx.doi.org/10.1155/2015/397128

CORAL, D.F,, PINEDA-GOMEZ, P., ROSALES-RIVERA, A., RODRIGUEZ GARCIA, M.E. 2009. Determination of the gelatinization temperature of starch presents in maize flours. Journal of Physics: Conference Series : $1-5$ https://doi.org/10.1088/1742-6596/167/1/012057

EERLINGEN, R., DELCOUR, J. 1995. Formation, analysis, structure and properties of type III enzyme resistant starch. Journal of Cereal Science, 22,129138. https://doi.org/10.1016/0733-5210(95)90042-X
FADDA, C., SANGUINETTI, A.M., DEL CARO, A., COLlAR, C., PIGA, A. 2014. Bread staling: Updating the view. Comprehensive Reviews in Food Science and Food Safety, 13(4), 473-492. https://doi.org/10.1111/1541-4337.12064

FIK, M., MICHALCZYK, M., SURÓWKA, K., MACIEJASZEK, I. 2000. Characterization of the staling process of wholemeal bread. Polish Journal of Food and Nutrition Sciences, 9(50), 23-28.

FIK, M., SURÓWKA, K., MACIEJASZEK, I., MACURA, M., MICHALCZYK, M. 2012. Quality and shelf life of calcium-enriched wholemeal bread stored in a modified atmosphere. Journal of Cereal Science, 56, 418-424. https://doi.org/10.1016/j.jcs.2012.06.006

FUENTES-ZARAGOZA, E., RIQUELME-NAVARRETE, M.J., SÁNCHEZZAPATA, E., PÉREZ-ÁLVAREZ, J.A. 2010. Resistant starch as a functional ingredient: A review. Food Research International, 43, 931-942. https://doi.org/10.1016/j.foodres.2010.02.004

FUNAMI, T., KATAOKA, Y., OMOTO, T., GOTO, Y., ASAI, I., NISHINARI, K. 2005. Effects of non-ionic polysaccharides on the gelatinization and retrogradation behavior of wheat starch. Food Hydrocolloids, 19, 1-13. https://doi.org/10.1016/j.foodhyd.2004.04.024

GAMBUŚ, H. 2005. Nasiona lnu oleistego (Linum usitatissimum L.) jako źródło składników odżywczych w chlebie bezglutenowym. Żywność. Nauka. Technologia. Jakość, 4 (45) Suppl., 61-74.

HARALAMPU, S.R. 2000. Resistant starch - a review of the physical properties and biological impact of RS. Carbohydrate Polymers, 41, 285292.https://doi.org/10.1016/S0144-8617(99)00147-2

ISHIGURO, K., NODA, T., KITAHARA, K., YAMAKAWA, O. 2000. Retrogradation of Sweet potato Starch. Starch/Stärke, 52, 13-17. https://doi.org/10.1002/(SICI)1521-379X(200001)52:1\%3C13::AID-

STAR13\%3E3.0.CO;2-E

KARIM, A.A., NORZIAH, M.H., SEOW, C.C. 2000. Methods for the study of starch retrogradation. Food Chemistry, 71, 9-36. https://doi.org/10.1016/S03088146(00)00130-8

KIATPONGLARP, W., TONGTA, S., ROLLAND-SABATÉ, A., BULÉON, A 2015. Crystallization and chain reorganization of debranched rice starches in relation to resistant starch formation Carbohydrate Polymers, 122, 108-114 https://doi.org/10.1016/j.carbpol.2014.12.070

KIM, W.K., CHUNG, M.K., KANG, N.E., KIM, M.H., PARK, O.J. 2003. Effect of resistant starch from corn or rice on glucose control, colonic events, and blood lipid concentrations in streptozotocin-induced diabetic rats. The Journal of Nutritional Biochemistry, 14, 166-172. https://doi.org/10.1016/S09552863(02)00281-4

KOTSIANIS, I.S., GIANNOU, V., TZIA, C. 2002. Production and packaging of bakery products using MAP technology. Trends in Food Science and Technology, 13, 319-324. https://doi.org/10.1016/S0924-2244(02)00162-0 KRALA, L., KIJOWSKI, J. 2013. Chłodnicze przechowywanie mięsa i przetworów drobiowych pakowanych w modyfikowanej atmosferze (MAP). W: Gaziński, B. (ed). Przechowalnictwo Żywności, Poznań: Systherm Technik. ISBN

978-83-61265-76-4

KRYSTYJAN, M., ADAMCZYK, G., SIKORA, M., TOMASIK, P. 2013. Longterm storage stability of selected potato starch - non-starchy hydrocolloid binary $\begin{array}{llll}\text { gels. } & \text { Food Hydrocolloids, } & 31, & 270-276\end{array}$ https://doi.org/10.1016/j.foodhyd.2012.10.024

LE BAIL, A., BOUMALI, K., JURY, V., BEN-AISSA, F., ZUNIGA, R. 2009. Impact of the baking kinetics on staling rate and mechanical properties of bread crumb and degassed bread crumb. Journal of Cereal Science, 50, 235-240 https://doi.org/10.1016/j.jcs.2009.05.008

MAJZOOBI, M., RADI, M., FARAHNAKY, A., JAMALIAN, J., TONGDANG, T., MESBAHI, GH. 2011. Physicochemical Properties of Pre-gelatinized Wheat Starch Produced by a Twin Drum Drier. Journal of Agricultural Science and Technology, 13, 193-202.

MEGAZYME. 2002. Resistant Starch Assay Procedure. AOAC Method 2002.02. AACC Method 3241

MORRIS, V.J. 1991. Weak and strong polysaccharide gels. In: Dickinson, E (ed). Food Polymers, gels and colloids. London: The Royal Society of Chemistry, Cambridge, p. 310. ISBN 0-85186-657-3.

NOVOTNI, D., ĆURIĆ, D., GALIĆ, K., ŠKEVIN, D., NEĐERAL, S. KRALJIĆ, K., GABRIĆ, D., JEŽEK, D. 2011. Influence of frozen storage and packaging on oxidative stability and texture of bread produced by different processes. LWT - Food Science and Technology, 44, 643- 649 https://doi.org/10.1016/j.lwt.2010.11.020

PATEL, B.K., WANISKA, R.D., SEETHARAMAN, K. 2005. Impact of different baking processes on bread firmness and starch properties in breadcrumb. Journal of Cereal Science, 42, 173-184. https://doi.org/10.1016/j.jcs.2005.04.007

PHILLIPS, C.A. 1996. Modified atmosphere packaging and its effects on the microbiological quality and safety of produce. International Journal of Food Science and Technology, 31, 463-479. https://doi.org/10.1016/j.jcs.2005.04.007 PLESSAS, S., ALEXOPOULOS, A., BEKATOROU, A., MANTZOURANI, I. KOUTINAS, A.A., BEZIRTZOGLOU, E. 2011. Examination of freshness degradation of sourdough bread made with kefir through monitoring the aroma 
volatile composition during storage. Food Chemistry, 124, 627-633. https://doi.org/10.1080/13102818.2014.918701

POLISH STANDARD. 1996. Bread. Testing and Grading. PN-A-74108:1996.

PRIMO-MARTIN, C., VAN NIEUWENHUIJZEN, N.H., HAMER, R.J., VAN

VLIET, T. 2007. Crystallinity changes in wheat starch during the bread-making process: Starch crystallinity in the bread crust. Journal of Cereal Science, 45, https://doi.org/10.1016/i.jcs.2006.08.009

RASMUSSEN, P.H., HANSEN, A. 2001. Staling of Wheat Bread Stored in Modified Atmosphere. LWT - Food Science and Technology, 34, 487-491. https://doi.org/10.1006/fstl.2001.0793

RIBOTTA, P.D., CUFFINI, S., LEON, A.E., ANON, M.C. 2004. The staling of bread: an X-ray diffraction study. European Food Research and Technology, 218 219-223.

RONDA, F., CABALLERO, P. 2011. Staling of frozen partly and fully baked breads. Study of the combined effect of amylopectin recrystallization and water content on bread firmness. Journal of Cereal Science, 53, 97-103. https://doi.org/10.1016/j.jcs.2010.10.003

SIEVERT, D., POMERANZ, Y. 1990. Enzyme-Resistant Starch. II. Differential Scanning Calorimetry Studies on Heat-Treated Starches and Enzyme-Resistant Starch Residues. Cereal Chemistry, 67(3), 217-221.

SKOTNICKA, M., PALICH, P. 2007. Wpływ warunków przechowywania na stopień czerstwienia mrożonych wyrobów ciastkarskich. Żywność. Nauka. Technologia. Jakość, 5(54), 84-92.

TOPPING, D.L., CLIFTON, P.M. 2001. Short-chain fatty acids and human colonic function: Roles of resistant starch and nonstarch polysaccharides. Physiological Reviews, 81, 1031-1064.

YU, H., CHENG, L., YIN, J., YAN, S., LIU, K., ZHANG, F., XU, B., LI, L.

2013. Structure and physicochemical properties of starches in lotus (Nelumbo nucifera Gaertn.) rhizome. Food Science and Nutrition, 1(4), 273-283. 